\title{
A cognitive linguistic approach to the emotion of anger in the Old Testament
}

\author{
Zacharias Kotzé \\ Department of Ancient Studies \\ University of Stellenbosch
}

\begin{abstract}
This article reviews several approaches to the study of anger in the Old Testament. It focuses on the use of methodology in these trends with specific reference to the common neglect of Classical Hebrew terminology and expressions relating to the emotion of anger. Such styles lead to an impoverished understanding of the ideal cognitive model of anger as reflected in Classical Hebrew. By contrast, the few recent cognitive linguistic studies on the same subject prove to be far more successful in giving a detailed account of the ancient Israelite conceptualisation of this emotion.
\end{abstract}

\section{INTRODUCTION}

The study of anger and aggression is of chief importance to modern research. Its understanding and control is paramount to stability and our survival on earth. Despite the numerous works available on the theme of anger in the Old Testament deep insight into its nature as conceptualised by the ancient Israelites is incomplete. This lack of detailed information is primarily due to the fact that most scholars have approached the topic from a restricted theological perspective. As a rule, Classical Hebrew has been rejected as a suitable tool for the study of such an important subject. Anger is generally viewed as an abstract concept that can be separated from the terms and linguistic expressions describing this emotion in the Hebrew Bible. Predictably, the majority of researchers have adopted study procedures that allow them to give little thought to the Hebrew language of anger.

Most studies on anger in the Old Testament restrict their attention to the function of divine anger as illustrated in the history of ancient Israel (Boegner 1878; Kilpatrick 1908; Köhler 1966; Aloysia 1946; Hanson 1946; Morris 1952; Simpson 1952; Haney 1960; Eichrodt 1961; Heschel 1962; Vögtle 1965; Stöger 1970; Tasker 1980; Westermann 1981; Herion 1992; Faessler 1997; Baloian 1997). Others have tried to define this emotion in the context of the anthropology of the Old Testament, which they have derived 


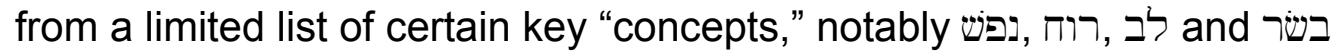
(Robinson 1925; Weill 1926; Pedersen 1959; Johnson 1964; Von Meyenfeldt 1950; Köhler 1953; Schmidt 1964; Wolff 1973; Lauha 1983; Ben-Chorin 1986; Brotzman 1988; North 1995; Schroer \& Staubli 1998). This disregard for the Classical Hebrew expressions relating to the emotion of anger is unfortunate in view of their value as a source for the study of cultural concepts.

In recent years it has been found that everyday language reveals much about a culture's cognition (see, e g, Lakoff \& Johnson 1980; Dirvin 1995). Experiential factors, especially with regard to the body, give rise to the formation of linguistic expressions that can be studied successfully to lay bare the cultural understanding of abstract concepts, such as the emotions (Kövecses 1990, 1995a, 2002). Further, in view of the fact that the physiology of emotional experience is largely universal (see, e g, Ekman, Levenson \& Friesen 1983; Levenson et al 1991; Levenson et al 1992), one can expect to find similar concepts of the same emotion in divergent cultures spanning the boundaries of time and nationality (see, e g, Kövecses 1995b; Matsuki 1995; Yu 1995; Mikolajczuk 1998; Taylor \& Mbense 1998). Therefore, although at first it might seem questionable to claim that the ancient Israelites conceptualised anger in a similar way to contemporary English-speaking people, this theory indeed seems plausible in view of present evidence (see, e g, Dhorme 1963; Gruber 1980; Smith 1998; Kruger 2000a, 2001; Kotzé 2004). This, of course, does not imply that the ancient Israelites did not have very distinct concepts of the emotion as well (see, e g, Kotzé 2004).

Before examining the cognitive linguistic theory of emotion conceptualisation in more detail, the limitations of current theological and anthropological trends of research will first be outlined.

\section{THE THEOLOGY OF ANGER IN THE OLD TESTAMENT}

For the most part, theologians have been extremely embarrassed by the explicit way in which divine anger is described in the Old Testament. Marcion, for example, went so far as to totally reject the God of the Hebrew Bible on the grounds that he was driven by anger and passion, merciless in his judgement and the precipitator of wars (Von Harnack 1985:85). All through the history of Christianity, theologians have preferred a God who demonstrates the essential quality of impassibility, in accordance with the Stoic ideal of apathy (ámá $\theta \in \iota \alpha$ ) (cf Hallie 1967). As a consequence, most works on the topic of anger in the Old Testament have endeavoured to define anger as a principle of just and controlled retribution. The first and most difficult task of such an enterprise would be to dismiss the explicit Classical Hebrew terminology of anger as insignificant. 
Boegner (1878:248-249) holds that anger terms merely describe the

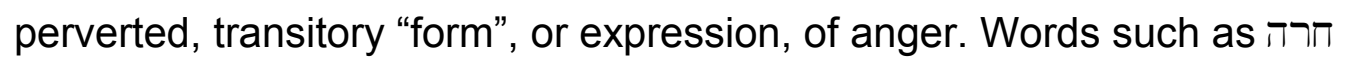
"burn," עברה "boil over" are inappropriate to express the eternal and natural "essence" of anger. Perfect anger, as exemplified by a just and holy God, is passive and devoid of any 'form' that may be implied by language.

Although most studies on the topic of anger in the Old Testament briefly consider the meaning of relevant Classical Hebrew terms, many theologians have thought an investigation of terminology superfluous. For example, Kilpatrick (1908:477) merely concerns himself with contrasting the "finitude and imperfection" of human anger with the "absolute perfection" of divine anger, which is justified in view of the sin and hostility of man (Kilpatrick 1908:477).

Köhler (1966:34-6) regards divine anger to be coupled with the concept of holiness. God's holiness implies that he is totally free from the interference of sensations, including anger, which puts him in total control of his own actions (Köhler 1966:34). Descriptions of divine anger in the Old Testament are therefore no more than accounts of justifiable retribution.

Aloysia (1946:407) warns against seeing the Old Testament as "a source from which may be drawn instances of swift and dire punishment." Rather, divine anger is always a result of human sin and there was always the promise of his anger calming down in the event of repentance (Aloysia 1946:411). God's anger is therefore controlled and rational.

Hanson (1946-7) identifies divine anger with jealous love. This divine love and jealousy is of a different quality than any other, since it claims the right to our allegiance: "Man must encounter that love; if he accepts it, in the form of love; if he rejects it, in the form of wrath" (Hanson 1946-7:217). In this innovative way, Hanson succeeds in justifying divine wrath without detailing its nature as a unique emotion.

Morris (1952:142) finds it unfortunate that most theologians define anger in the Old Testament as an attribute rather than an emotion. However, he too merely describes it as divine reaction to human sin (Morris 1952:143). In its true essence, divine anger is "a fiery zeal for the right in the service of the highest moral ends" (Morris 1952:144). It is subjugated to divine love and free of "passion" and the loss of self-control.

Simpson (1952) also regards divine anger to be outweighed by his love and mercy. Rather than being an arbitrary and malicious emotion, it is a permanent state of retributive justice based on the covenant, which, on its turn, is based on God's desire to love a particular people (Simpson 1952:1135). 
Haney (1960:15) dismisses the etymology of Classical Hebrew words for anger on the grounds that it is inconsequential and non-distinctive. This allows him to view anger in the Old Testament as dispossessed of emotional components of feeling. Further, it is in total harmony with the ethical principles of justice, love and faithfulness (Haney 1960:74-75).

Eichrodt (1961:258-269), too, regards the Hebrew language to be of no consequence with regard to the true nature of anger. Terms that refer to experiential aspects of the emotion, such as burning (חמה ;חרון), snorting (רוח); אף), foaming (זעם זעף), boiling over (עבר) and the breaking forth of something under pressure (קצב), are distinct from the real sense of anger, which was changed by the Sinai covenant. Anger, as described in the Old Testament, is "reaction against offence against the covenant or its Creator" (Eichrodt 1961:259). Evidently, anger words and expressions have played no role in Eichrodt's final definition of anger in the Old Testament.

In the same way, Heschel (1962:61) holds that Hebrew terminology is unsuitable for a description of the true nature of anger since it suggests a "loss of self-control, compulsiveness, temporary derangement of the mind and the desire or intent to avenge or punish." Anger in the Old Testament is not an incontrollable "passion," but "pathos." As established by a sovereign, righteous and free God, it is not an emotion, but a permanent disposition governed by love and mercy (Heschel 1962:62).

Vögtle (1965:1403-1405) focuses on figurative expressions in his criticism of the Hebrew language of anger. Vögtle (1965:1404) finds it regrettable that symbols, such as fire, wine-cup and breath were used to describe anger in earlier writings, since they imply something irrational. Their incongruity with the concept of anger as deserved castigation for sin was evidenced by the fact that they were almost entirely discontinued in the New Testament, which speaks of divine wrath as superseded by divine love.

Similarly, Stöger (1970:1006-7) rejects anger terminology as a suitable vehicle for the Old Testament concept as anger as the reaction of a loving God to the violation of the covenant. For him, linguistic expressions of anger are anthropomorphisms that were discontinued in later writings due to their incompatibility with the real nature of anger, which, in later writings, ceased to be an emotion. The description of anger "as an inner fire, and its effect as the snorting, foaming, boiling, and bursting of pent-up energy" (Stöger:1007) was therefore withdrawn.

According to Tasker (1980:1657), Hebrew terminology for anger suggests "something wayward, fitful and spasmodic." For this reason it is unsuitable to describe divine anger, which is "the permanent attitude of the holy and just God when confronted by sin and evil” (Tasker 1980:1657). 
Although Westermann (1981:147-156) considers the concepts that may be implied by the Classical Hebrew terminology of anger in a few words, he also regards these to be unconnected to the real nature of anger as demonstrated in the history of ancient Israel. His cut down definition of divine anger as divine judgement (Westermann 1981:153) is unrelated to any study of Classical Hebrew terms and expressions for anger.

Herion (1992:989-996) follows Heschel (1962) in differentiating between the "passion" and the "pathos" of anger. The meanings of the Classical Hebrew terms for anger describe the "passion" of anger as the human loss of self-control. This "passion" as expressed in language is in conflict with the dominant concept of anger in the Old Testament as a controlled, ethical principle of just punishment for sin.

Baloian (1992:5-7) briefly considers words for anger in the Old Testament in view of their meanings. For real conceptual content, however, he turns to the theology of the Old Testament. Both his monograph (Baloian 1992:20-28) and his article (Baloian 1997:377-378) emphasise Biblical admonitions to control anger. Baloian (1997:380-381) further regards the Old Testament concept of anger to imply judgement proceeding from a just and legal context rather than emotional passion.

Faessler (1997:91-108) regards Hebrew words and expressions for anger to be applicable only to human anger, which is characterised by impatience, blindness, uncontrollability and loss of speech (Faessler 1997:9396). His target, by contrast, is to point up "la 'sainte colère' de Dieu biblique." He tactically chooses to analyse the story of the Golden Calf in Exodus 32, which illustrates that God is in total control of his anger.

All the studies listed above have tried to describe anger as a theological concept devoid of emotional content. Most of the theologians have dismissed Hebrew terminology as non-distinctive and immaterial for the study of the ancient Israelite conceptualisation of anger. Classical Hebrew data, however, points to an ideal cognitive model of anger that can by no means be reduced to a concept of just retribution for wrongdoing. The ancient Israelites drew from the totality of their human experience to characterise both human and divine anger by means of language.

Although sociological and anthropological studies of the ancient Israelite culture have contributed more to a better understanding of the conceptualisation of emotions in the Old Testament, the insight gained from these is restricted due to a limited focus on a few selected key concepts. 


\section{ANGER IN SOCIOLOGICAL AND ANTHROPOLOGICAL STUDIES OF THE ANCIENT ISRAELITE CULTURE}

The value of sociology and anthropology for a better understanding of the Old

Testament cannot be denied (cf Kruger 2000b:137-173). For example, with regard to the emotions, scholars have shown how the fear of supernatural dangers gave rise to purity laws and ritual (cf Smith 1923:152-154; Frazer 1934; Douglas 1975; Caplice 1974). These findings have been applied successfully by theologians to make sense of the, often ambiguous, purity regulations (cf Kutsch 1965:28; Wenham 1981, 1983; Wright 1987; Podella 1997).

However, these studies are of limited value to an understanding of ancient Israelite conceptions of the emotions since they only identify conscious and subconscious causes of fear and its expression in ritual. Therefore, we will restrict our survey of anthropological approaches to those that are expected to have implications for an appreciation of the concepts of anger as they relate to physical experience and expression.

The discovery of the central nervous system and its implications for cognition and emotion in the eighteenth and nineteenth centuries led to a slow abandonment of the Greek notion of an incarnated soul. Old Testament scholars then tried to contrast Israelite thinking with that of Greek, claiming that the unity of soul and body was always implied by the ancient Israelites. Therefore, the Greek dualism of soul $(\pi \nu \in \hat{v} \mu \alpha)$ and body ( $\sigma \alpha \dot{\rho} \xi)$, especially in the Pauline epistles, was foreign to Israelite thinking.

Part of the quest to describe the Hebrew thinking as devoid of dualism, was to show that the words that were usually translated as soul (נפש) and spirit (רוח) in fact often refer to material things. Weill (1926:62-63), for example, shows that נפש could be used to speak of the throat. Others tried to uncover some holistic Hebrew thinking in the use of such terms.

Robinson (1925) holds that the failure to distinguish between the material and spiritual is a common trait of "primitive peoples":

The primitive Semitic idea of man seems to have been very much like that which we find amongst other primitive peoples, of the ancient or of the modern world. There is no distinction of the psychical and ethical from the physical, so that the actual breath of man can be thought of as his "soul", and the reek of hot blood identified with this breath-soul. Psychical and ethical functions are considered to be just as appropriate to the bodily organs as the physiological. 
Further, Robinson is of the opinion that the ancient Israelites assigned to bodily organs psychical functions due to their ignorance of the brain and central nervous system. He develops the notion of a diffusion of consciousness:

Though there was entire ignorance of the nervous system, man's consciousness, with its ethical qualities, was thought to be so diffused through the whole body that the flesh and bones, as well as the mouth, eye, ear, hand, had a quasi-consciousness of their own. Man's organism is in fact a "United States," rather than a monarchic or imperialistic realm.

(Robinson 1925:354)

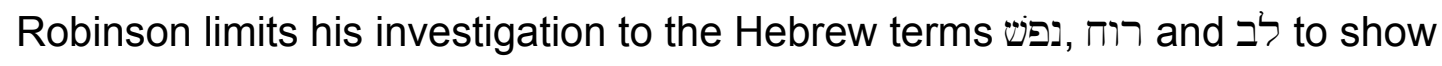
how Hebrew psychology was tied up with their conception of the body. He (Robinson 1925:355) argues that נפש later was used to speak of the body, which suggests that, "the body is the predominant partner in the Hebrew idea of personality." Robinson (1925:361) concludes that נפש and רוח designates the same thing, namely the conscious life of man, associated with the breath as the vital principle. They were used to talk about the "breath-soul" which primarily represented emotional phenomena. In fact, for Robinson (1925:361) it symbolises much more, "... because 'spirit' originally denoted an energy acting on man from without, a divine energy, it naturally suggests a higher conception of the life of man, as drawn from God." This spiritualisation of the emotional life of the Hebrew man leads him to, for example, declare Saul's anger and madness as "inspired" by the "energy (רוה) of YHWH" (Robinson 1925:358-359).

The rest of the organs denote the "heart-soul," due to its chief importance (Robinson 1925:362-364). לב is used to suggest the mental rather than emotional activities of consciousness. According to Robinson (1925:363364 ) its most important and characteristic use is for volition, which is primary in Israelite ethics.

Robinson's unwillingness to accept that body parts could have been used metaphorically to refer to perceived bodily changes accompanying specific emotions is a major drawback in his work. This prevents him from recognising a clearer structure in the emotional conceptualisation of the ancient Israelites, and he concludes: "The usage of psychological terms in the Old Testament is not systematic, but syncretistic; a number of originally independent explanations, such as blood-soul, breath/soul, heart, et cetera have been brought together by popular use, and have settled down into a sort 
of working agreement and division of labour, though with much overlapping" (Robinson 1925:354).

More recently it has been realised that the psychological use of body parts in the Hebrew Bible are due to the actual physical sensations felt during specific emotional episodes (Smith 1998) and that they can refer to specific conceptualisations of such distinct emotions (Kruger 2000a, 2001).

Pedersen (1959:99-262) also thought of the Hebrew soul not as part of the body, but rather as denoting man in its totality. Pedersen (1959:171) refers to the creation story to illustrate this inseparability of body and soul: "The man of clay was a dead thing, but by the breath of God he was entirely changed and became a living soul. Soul and body are so intimately united that a distinction cannot be made between them. They are more than "united": the body is the soul in its outward form."

Like Robinson, he argues that this idea of unity was essentially expressed by the Hebrew words נרב (1959:102-106), but also includes other organs in his review (Pedersen 1959:171-175). These organs are so filled with soul that their movement should not be seen as the expression of inner states. More precisely, these are the activities of the soul itself:

All of these examples show how the Israelite sees the soul manifesting itself in the body. It bears witness to his psychological observation and his sense of reality. He concludes not from the movements of the body to an underlying soul, which uses and moves the body, but in the activity of the soul he sees the soul itself.

(Pedersen 1959:176)

Pedersen's descriptions of the ancient Israelite "soul" include a lot of indirect descriptions of several emotions, but unfortunately they lack completeness and cohesion due to his determination to denote the Hebrew man as a soul. His results are further impaired by his focal interest in the terms נפשיש and לב. Yet another important drawback is his simplistic translation of these terms as "soul". Their metaphoric use with reference to the physiology of the emotions seems to go completely unnoticed. For example, there are instances where רוח clearly refers to the blowing through the nostrils when experiencing an intense form of anger (cf Job 4:9; Ps 18:15[16]).

Johnson (1964) adopts the same approach to the study of Hebrew psychology as Robinson and Pedersen. References to parts of the body indicate psychic activities, and therefore prove that the ancient Israelites 
thought of man to be a psychophysical whole: "The conception of man as a psycho-physical organism may be seen equally clearly when one examines the use of the terminology for the various parts of the body; ... they are sometimes spoken of as themselves actively engaged in some form of personal behaviour or as characterised by some personal quality" (Johnson 1964:37).

Johnson (1964:2-3) makes נפש the main focus of his study, but maintains that "the soul-stuff or soul-substance is perceived, not only in the various members and secretions of the body, but also in a more extended form in whatever bears traces of contact with him." For example, he illustrates how the face could reveal various emotions, moods, and dispositions (Johnson 1949:40-1). It is described as expressing anger (Gn 31:2, cf $v 5$ ), joy (Job 29:24), fear (Is 13:8; Ezk 27:35; Jl 2:6; Nah 2:11), anguish (Jr 30:6), or some corresponding form of distress (Gn 40:7; Job 16:16; Ec 7:3; Neh 2:2, 3).

Johnson is one of the first to admit the metaphoric use of body parts to speak of physiological changes accompanying certain emotions. About נפש he writes that it was used to denote breathing as a metonymy of anger: "Indeed there is something of a parallel in the case of the term $¥ s$, which could be used equally well of the 'nostril' and of that quick nasal breathing which is indicative of anger" (Johnson 1964:6-7).

Johnson's work added valuable insight in the ancient Israelite conception of a wide range of emotions. Unfortunately, he often glosses over the use of emotion terminology and presents no integrated conceptual model for distinct emotions.

Johnson (1964:39) also criticises Robinson's theory of the "diffusion of consciousness" on the basis that the different parts of the body are often used as synecdoches for a man's person or self as a whole. For example, the bones (עצם) are said to decay or become soft with fear or distress (Hab 3:16; Jr 23:9) and so "provide an obvious parallel to the term נפשי" (Johnson 1964:67-68). Unfortunately, in seeing עצש בצש abvious a synecdoche for metaphoric use referring to bodily sensations as felt in the event of fear is ignored.

Von Meyenfeldt (1950:137-142) gave only passing attention to the heart being used in the context of emotion. He saw its primary function as reinforcing emotions such as distress and joy. This is especially true when used with the prepositions על על מל מא: "Beide voorzetsels zijn richtingaangevend, in dit geval de richting van de oppervlakte naar de diepte. Het is geen overdreven, maar echte smart" (Von Meyenfeldt 1950:137). The incomprehension of subjective feeling as source of these expressions is once again striking. This is also true of his review of לב's use to speak of other 
emotions. With regard to fear, for example, he lists the passages where it occurred, noted that the heart is said to become weak, melt away, and shiver (Von Meyenfeldt 1950:139-140). From this he concluded that the heart was conceptualised as a mouldable or fusible substance (Dutch: kneedbare of smeltbare massa), and a suitable breeding place for anxiety (Von Meyenfeldt 1950:140). No further attempt is made, however, to give an account of the cultural conceptualisation of these emotions as they relate to subjective experience. Hence, the insights gained remain superficial and incomplete.

Köhler (1953:101) is very reluctant to attempt a coherent and understandable description of the psychological world of the ancient Israelites, since he feels that such an exercise would be futile. Köhler is of the opinion that the emotional life of an ancient culture is relatively "dry" compared to that of a contemporary culture. By "dry" he does not mean cold-blooded. About the "Hebrew Soul" he claims that, "Sie ist rascher, aber nicht bloß rascher, sondern auch stärker, leidenschaftlicher, bis ins äußerste hinein bewegbar und erregbar" (Köhler 1953:109).

Unfortunately Köhler (1953) does not believe that a description of the ancient Israelite conception of emotion would be possible, since, according to him, modern cultures had complex systems of emotional meaning, and it would be too difficult to describe psychological phenomena of an ancient culture in modern words and concepts: "Darum wäre es untunlich, in einem geschlossenen Gefüge die Einzelseiten des geistigen Bildes des hebräischen Menschen abhandeln zu wollen. Viele Seiten blieben inhaltslos, und das Ganze der Darstellung böte sich als ein trockenes und wenig, wenn nicht nichts sagendes Nacheinander von Angaben dar" (Köhler 1953:101).

Schmidt (1964:374-90) is concerned about the way in which the "concepts" בשטר are usually translated. Just like his predecessors (cf Robinson 1925; Pedersen 1959; Johnson 1964) Schmidt is worried that a translation of these terms might wrongly convey some implied dualisms:

Zwischen der eigenen Wiedergabe und den Texten selbst besteht ein charakteristischer Unterschied in den Begriffen. Die Wahl anderer Begriffe zieht jedoch einen Unterschied in der Sache nach sich. So gewichtige, bei der Exegese oft vorausgesetzte Gegensätze, wie Form und Inhalt, Körper und Seele oder Geist, Physisches und Psychisches oder Geschichte und Natur, sind dem Alten Testament fremd. 
As a student of Wolff (cf Anthropologie des Alten Testaments, 1973), Schmidt (1964:375) wanted to answer the question: "Wie denkt das Alte Testament selbst." He is of the opinion that the answer lies in the Hauptbegriffen vom Menschen, namely בשר and רוח a בש:... der Sache nach [ist] in allen drei Begriffen nicht jeweils ein Teil des Menschen neben anderen, sondern der Mensch als ganzer und als Einheit gemeint" (Schmidt 1964:376).

Schmidt goes on to list all the different possible meanings of these terms. Unfortunately, his analysis of their use with relation to emotion is very brief. He points out that to be "short of נפשי" meant to be impatient ( Nm 21:4; Jdg 10:16, 16:16; Zch 11:8), whereas being "Iong of נפש (Ezk 6:11), "denn bei Ungeduld atmet man schneller, während eine 'langatmige' Rede die Geduld des Hörers beansprucht" (Schmidt 1964:380). Schmidt (1964:382) argues that רוח is often used to designate the seat of feelings, and can become bitter, or anguished (Gn 26:35). Similarly, לב could shiver when afraid (Is 7:5; cf. Ps 27:3) (Schmidt 1964:383-6).

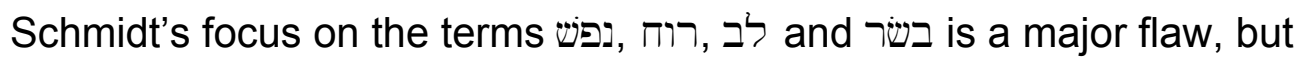
at least he is aware of the fact that some expressions on the subject of emotions had their origin in subjective experience.

Wolff's (1973) approach to ancient Israelite psychology does not differ much from that of Robinson (1925), Pedersen (1959), Johnson (1964) and Schmidt (1964) in that he makes specific terms (G. Begriffe) his point of departure in his attempt to describe ancient Israelite anthropology. His list of

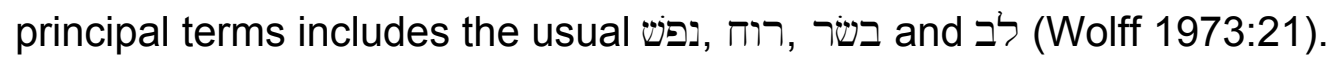
Again, the main concern is to prove that these terms did not reflect any dualism in thinking:

\begin{abstract}
Wenn die häufigsten Hauptwörter in der Regel mit "Herz", "Seele", "Fleisch" und "Geist" übersetzt werden, so sind damit folgenschwere Missverständnisse erzeugt worden. Sie gehen schon auf die altgriechische Übersetzung der Septuaginta zurück und verführten zu einer dichotomischen oder trichotomischen Anthropologie, in der der Körper und die Seele und der Geist in Gegensatz zueinander geraten.
\end{abstract}

(Wolff 1973:21)

Consequently, as with the other anthropologists, these terms' use in emotional contexts received only secondary attention. For example, Wolff (1973:35-37) thinks that נפש, although often used in relation to several different emotions, primarily denoted man in need. When meaning "throat" it can also mean "breathing," just as "nose" can be used metaphorically to denote "breath", so 
that "das Organ der Atmung und der Atem selbst zusammengesehen werden" (Wolff 1973:29). Again no structured conceptual model for any emotion is attempted.

Lauha (1983:22) is aware of the limitations of an attempt to find emotional meaning through an exclusive focus on the terms לב and and רוח Lauha (1983:10-24) criticises the Sapir-Whorf hypothesis, as expressed by Wolff (1973), Pedersen (1959) and Johnson's (1964) theory that ancient Israelite language determined Hebrew thinking. Rather, everyone is born with a pre-programmed universal grammar, which means that there is no word or concept in one language that cannot be adequately translated into another (Lauha 1983:15). Further, Lauha (1983:24-30) sees a distinct danger in any approach that limits its investigation to isolated terms. This, he claims (Lauha 1983:26-27), could lead to illegitimate meanings being ascribed to such words. One should rather identify a semantic field and consider all the different words that add to the meaning of this concept (Lauha 1983:24-28).

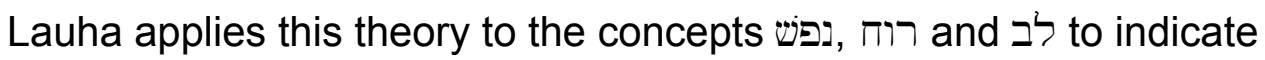
how they are used with other roots to typify joy, mourning and pain, courage, fear, pride, humility, love, hate and anger. Let's consider his results with regard to the emotion of anger.

לב is sometimes used with expressions of heat to speak of anger (Lauha 1983:224). In Deuteronomy 19:6 it is said of a person that takes revenge that his heart burns: כי חמם לבבו (see also Ps 39:4). The imagery of fire wis and smoke (עשן) is also quite common in this context (Lauha 1983:224). נפש cand and an also denote anger on their own (Lauha 1983:227). In Proverbs 29:11 the expression רוחו יוציא means giving free vent to one's anger (Lauha 1983:152).

Lauha identifies numerous roots and expressions for anger. However, since he was primarily interested in the semantics of נפש and לב רב he showed little interest in the possible conceptual content that these might have had. Consequently, for example, he declines any attempt to link anger with breath (Lauha 1983:228). Nevertheless, his lists of words relating to the semantic field of distinct emotions are comprehensive and estimable.

Lauha's study by no means heralds the cessation of endeavours to see in לב רוח , בפש a Hebrew anthropology of unity. Ben-Chorin (1986:55) denied the existence of a Pauline dualism between body and spirit in the Hebrew Bible. For him, בפש and are encompassed by the body בשר a רשח a

Brotzman (1988:400-409), too, saw נפש as a key term whose meaning pointed to a holistic view of man. He concludes that נפש basically meant "being" or "creature" as a unit, and that this "... is decidedly opposed to the 
common Greek idea of a "soul" imprisoned in a body, and to the idea expressed by some branches of Protestant and Roman Catholic thought that the pathway to righteousness is found by downplaying the body and encouraging 'the higher part of man'” (Brotzman 1988:407).

With regard to the emotions, Brotzman (1988:403-404) simply points out that the semantic fields of נפש and could overlap and they were used to allude to such emotions as impatience, bitterness and sadness. רוח on its own was used to speak of pride, humility, anger and self-control (Brotzman 1988:404). No consideration is given to its possible use as a tool to express conceptual meaning with regard to emotions (cf Can 5:6).

Schroer and Staubli (1998:68-73) were also quick to point to the inadequacy of $\psi \bar{u} \times \eta$ to translate נפש: "Denn die Seelenbegriff der griechischen Philosophie ist mit der hebräischen Vorstellung von der נפש überhaupt nicht zu vergleichen" (Schroer \& Staubli 1998:68). Its application to express emotion did not come into play in their work. Rather, emotion is localised in the organs (Schroer \& Staubli 1998:75). For example, the liver כבר was associated with grief (Lm 2:11) and happiness (Ps 16:9) (Schroer \& Staubli 1998:77). Also the heart and kidneys were referred to in the context of grief (Ps 73:21) (Schroer \& Staubli 1998:77). The loss of heart in the context of fear was also a common concept in the ancient Near East (Schroer \& Staubli 1998:48). Emotions such as sadness, fear, contempt and shame can be expressed in the face (Schroer \& Staubli 1998:95-97). Heavy breathing was equated with anger, which gave rise to the metaphoric use of $7 \mathrm{~s}$ in this context (Schroer \& Staubli 1998:105-106).

Schroer and Staubli devote little attention to emotional expression in the body. The traditional contrast between Greek and Hebrew thinking is evident, as well as the notion of emotion being located in body parts.

North (1995:33) also regards the heart as the seat of emotions. It can be gladdened ( $\operatorname{Pr} 27: 11$ ), saddened (Neh 2:2), frightened (1 Sm 4:13), courageous (2 Sm 17:10) and full of love (Dt 6:5). However, his way of proving the holistic ways of Hebrew thinking was to argue that the Israelites had an understanding of some central nervous system: "Ancient Israelites had no word for brain and did not associate thinking with the head. Instead, לב thought and will were entwined with what we call emotions. The biblical corresponded largely to the functioning of the nervous system, which the ancients identified as the internal organs of the torso" (North 1995:33).

We can conclude that the major interest in twentieth century research on emotion in the Old Testament concerned itself with proving that the ancient Israelites had a holistic view of man. A convenient and successful way to do this was to produce evidence that body parts were seen to be the seats of 
emotions. The recurrent argument is: since emotions are located in, or bound to body parts, they cannot exist apart from the body. Ergo, there is no Greek dualism in Hebrew thought.

Regrettably, this line of thinking obscured the fact that allusions to viscera and other parts of the human anatomy can be explained by the fact that the emotions in question were actually felt there (Smith 1998:427-436).

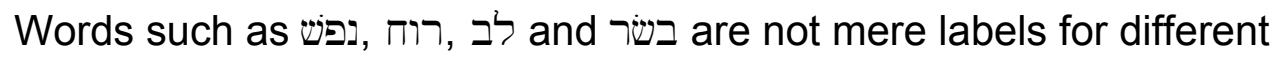
emotions. They are metaphoric ways of speaking about emotion whereby the ways in which the ancient Israelite experienced and understood their emotions are revealed (cf Kruger 2000a, 2001).

The study of the emotional use of language referring to human anatomy unquestionably added to our knowledge of the ancient Israelite conception of their emotions. In spite of the fact that the investigations were

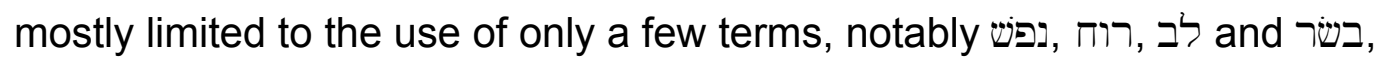
investigations such as the ones listed above led to a new appreciation of the uniqueness of the ancient Israelite way of thinking. From the above survey it is clear, however, that a full understanding of the psychology of emotions cannot be arrived at when the emotional use of these terms are considered only in a secondary sense. As a result no integrative, systematic description of the ancient Israelite perception of emotions has yet been achieved by this approach. This can partly be by reason of the fact that scholars have always been very hesitant to ascribe any structure to the psychological or emotional life of the ancient Israelites. Many have noticed the importance of such terms as רוח, רבש, and occasionally בשר in their conceptualisation of the emotions, but few have attempted a detailed description of distinct emotions.

\section{THE COGNITIVE INTERPRETATION OF ANGER LANGUAGE IN THE OLD TESTAMENT}

The study of the non-verbal communication of emotion in the Hebrew Bible is of special importance to a better understanding of ancient Israelite conceptions of anger. Darwin (1904:28) points out that: "Certain complex actions are of direct or indirect service under certain states of the mind, in order to relieve or gratify certain sensations, desires, etc; and whenever the same state of mind is induced, however feebly, there is a tendency through the force of habit and association for the same movements to be performed, though they may not be of the least use." It is therefore not surprising that somatic expressions of anger should have given rise to linguistic expressions denoting anger in Classical Hebrew.

Darwin makes use of examples from the Bible to illustrate how bodily action can be expressive of emotional states. With regard to fear, he holds: 
There is a well-known and grand description in Job: "In thoughts from the visions of the night, when deep sleep falleth on men, fear came upon me, and trembling, which made all my bones to shake. Then a spirit passed before my face; the hair of my flesh stood up: it stood still, but I could not discern the form thereof: an image was before mine eyes, there was silence, and I heard a voice, saying, Shall mortal man be more just than God? Shall a man be more pure than his Maker? (Job 4:13).

(Darwin 1904:308)

The Hebrew Bible being so rich in examples of the physical expression of different emotions, it is surprising that Darwin's work inspired so few Biblical scholars to do an extensive study of the subject (see also Kruger 1998). One of the first investigations of the subject in the Old Testament was done by Vorwahl (1932) more than half a century after Darwin's book on the expression of emotion was first published. Focussing on non-verbal expression in general, Vorwahl's treatment of specific emotions was perfunctory. The emotion of anger received little attention and his discussion of this spanned less than two pages (Vorwahl 1932:17-18).

On the subject of anger, Vorwahl reckons its manifestations in the Hebrew Bible to be associated with self-defence (Job 31:21), petulance in the context of fasting (Is 58:4; Job 31:21) and pride (Ex 17:11). The indications of anger that he identifies are hitting or waving with a fist (Is 9:10, 10:4, 58:4; Job 31:21; Ps 106:9), stretching out an arm (Gn 16:12; Ex 14:8, 17:11, 24:11; Is 5:25; cf. $\operatorname{Pr} 1: 24)$ and clapping of hands (Nm 24:10; Job 27:23). Vorwahl $(1932: 18)$ also argues that prints of the hand in Hebrew and Phoenician iconography should be interpreted as indicating threatening anger.

Vorwahl (1932:18) also identifies several facial indications of anger, namely the rolling of the eyes (Job 15:12), a sullen (רמז) or angry face (Dn 3:19), an evil look (Gn 31:2; Am 9:4), hiding of the face (Is 54:8; 59:2; Ezk 39:23; cf. Job 13:24) and steam escaping from the nostrils (2 Sm 22:9; Is 65:5; Ps 18:9, 74:1).

Vorwahl's work is followed by a long period of neglect with regard to the study of emotional expression in the Hebrew Bible. Fortunately, the recent upsurge in research on emotion coincided with serious attention being given to its expression, especially in the face (see, e g, Izard 1977). This renewed interest in emotion is also reflected in Biblical scholarship. Gruber's (1980) investigation of non-verbal communication in the ancient Near East included accounts of non-verbal indications of sadness, anger and happiness. Let us assess his description of anger expressions. 


\section{A cognitive linguistic approach to the emotion of anger}

Gruber (1980:483) made the very important observation that the "somatic expressions of anger should have given rise to verbs, nouns, and idioms denoting anger." With regard to the metaphoric use of 7 , he points to the limitations of approaches that viewed references to the organs as mere idioms expressing emotion: "Thus while experimental psychology demonstrates a direct connection between anger and specific somatic reactions including the face and the nose, standard reference works and specialized studies on Biblical Hebrew give the impression that any such connections reflected in Biblical Hebrew are to be regarded as at best arbitrary but more likely foolish" (Gruber 1980:486).

He listed the expression חרה אר as denoting "be angry" saying that it derived from the "well-known reddening of the faces of angry persons" (Gruber 1980:491). Other expressions derived from the same physiological

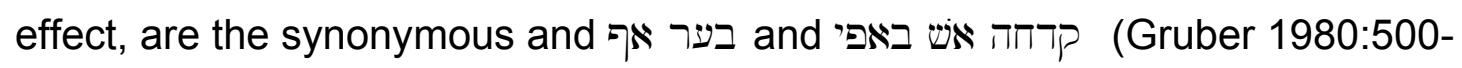
501). Gruber (1980:502-50) also identifies expressions for anger deriving from other physiological concomitants of anger. These include expressions stemming from frowning, such as קצר אפים (lit. "short of face") and החזיק אף, "to stiffen the face" (Gruber 1980:503). In addition, עלה עשן באפו "smoke went up from his nose" refers to the same effect as the English "fuming" to denote anger. Gruber (1980:510-50) furthermore argues that חמה אך should be rendered as "foaming at the mouth" as an expression of anger. He bases this argument on the fact that the primary meaning of חממה was "venom, poison" whose side effects could create effects similar to epileptic seizures. Anger could have been perceived as an extreme form of epilepsy (Gruber 1980:540).

The study of emotional expression made a very important contribution to our understanding of the ancient Israelite conception of emotion in that it shows that gestures and corporeal language are expressions of inner states, and thus have communicative intent. A study of a culture's perception about an emotion should therefore take its bodily expression seriously. However, since expression remains only one component of the overall emotional process (Scherer 2001), even a very detailed account of the expressive features of an emotion will not suffice to describe the cultural understanding of an emotion in a comprehensive way.

Dhorme (1963) comes close to a systematic description of the psychology of ancient Israel by taking a close look at the metaphoric use of body parts in Classical Hebrew and Akkadian. He is not interested in proving the homogeneity of an Israelite person, which allows him to see the real metaphoric value of the countless anatomic references in the Old Testament. Dhorme (1963:3) is concerned about the insufficiency of classification in 
dictionaries and wants to investigate the development of metaphoric meaning in Hebrew and Akkadian literature. A comparative study would not only reveal how the same images were used in different Semitic cultures, but also throw light on the more specific metaphoric use by biblical poets (Dhorme 1963:3). One brief example will suffice to illustrate his sensitivity to the origin of metaphors in sensation. About the nose, Dhorme (1963:80-1) holds that it was above all the organ of breathing, and it was the acceleration of nasal respiration that struck the Israelites as a symptom of anger. This symptom can be regarded as the source for the metaphor רוח אף, "breath of the nose", which is used to designate anger (Job 4:9). As might be expected, ఇא and אפים became synonyms for anger (Dhorme 1963:81). Dhorme (1963:81) clearly affirms that these expressions are due to the effects of anger on breathing: "Ce qui a permis cet usage, c'est l'influence de la colère sur la respiration" (Dhorme 1963:81). He goes on to illustrate how this physical concomitant of anger gave rise to other related metaphors: "Ainsi, dans Sir 5:11, nous aurons ארך רוח 'longueur de souffle' pour représenter la patience, ארך אפים 'longueur des narines' avec le même sens" (Dhorme 1963:81).

Although Dhorme is aware of anger's association with the heat metaphor (Dhorme 1963:81), he fails to point out that the expression חרה אף is probably derived from the perception of redness in the face of angry persons. Furthermore, "N's use with words expressing heat is far more recurrent than its use with רוח (cf Kruger 2000a). Thus, it is possible that „N's use referring to anger could be due to its becoming red during anger rather than its association with breathing.

Dhorme's cognisance of the organic basis of metaphors is commendable. However, since his primary interest was isolated metaphors rather than the conceptual models of emotion underlying these, metaphors of great import received only passing attention.

In his cognitive interpretation of anger language in the Hebrew Bible, Kruger (2000a) applies the Lakoff-Kövecses model of anger in American English to Hebrew data. The great success of this methodology testifies to the fact that emotion terminology has the experience of universal physiological changes as their source (Ekman et al 1983; Levenson et al 1991; Levenson et al 1992; Kövecses 1995b). Kruger (2000a:187-91) identifies six metaphors, namely, anger is the heat of a fluid in a container, anger is fire, anger is an opponent, anger is a dangerous animal, anger is presence and anger is bounded space. Kruger (2000a:191) also makes out one metonymy, which is violent, frustrated behaviour stands for anger. 
In another publication Kruger (2000c:155-162) further demonstrates the value of a cognitive linguistic approach to obscure terminology. He shows how the ambiguous כבד מש: in the cultic theophany of Isaiah 30:27 can be regarded as a vehicle for the entailment when the intensity of anger rises, the fluid rises of the compound metaphor anger is the heat of a fluid in a container. He aptly translates this locution with "his anger (lit. "his rising up") is overwhelming" (Kruger 2000c:162).

While not wide-ranging, the few cognitive linguistic studies on the topic of anger in the Old Testament listed above challenges the restricted theological interpretation of anger as a mere principle of justice.

\section{CONCLUSION}

Most of the studies on anger in the Hebrew Bible seem to have been dominated by theological intent, aiming only at some theological delineation of the wrath of God. This proves to be true even of entries in biblical lexicons and encyclopaedias. They all lacked interest in the cognitive interpretation of emotions by the ancient Israelites. Further, although biblical anthropologists succeed in giving an account of the different meanings of נפש , רוח , לב and בשר , a description of the emotion processes comprising different cognitive, psychological and physiological components is not arrived at (cf Frijda 1989; Kövecses 1995b; Scherer 2001; Ellsworth \& Scherer 2002). The listing of different expressive components of several emotions by Vorwahl and Gruber arguably come closer to an integrated conceptual definition of such emotions, but even here a lot of language relating to subjective feeling states seemed to have gone unnoticed (cf Smith 1998), thus leaving gaps in the picture.

For the most part, the subject of emotions in the Hebrew Bible is a derelict topic and deserves extensive treatment (Kruger 2000a:181). A mere study of anthropological terms expressing emotional meaning will not suffice. Even an intensive study of all the terms for a specific emotion will not serve the purpose, since conceptualisations about its physiology and phenomenology have to be inferred from metaphoric expressions (cf Kövecses 1990:32; Kruger 2000a:187-91, 2001:77-87). The studies listed above have shown that, in addition to the descriptive Hebrew terms for anger, there are numerous figurative expressions describing anger as an emotion. These figurative expressions had as their basis the physical experience of anger as well as environmental and cultural elements. A verifiable study of anger in the Old Testament needs to account for the concepts that these words and expressions stand for. The cognitive linguistic theory of metaphor seems to provide the ideal methodology for the scientific study of these emotion concepts. 


\section{Works consulted}

Aloysia, M 1946. The God of wrath? CBQ, 8, 406-415.

Athanasiadou, A \& Tabakowska, E (eds) 1998. Speaking of emotions:

Conceptualisation and expression. Berlin: Mouton.

Baloian, B 1992. Anger in the Old Testament. New York: Peter Lang.

Baloian, B 1997. s v Anger. New International Dictionary of Old Testament Theology and Exegesis.

Ben-Chorin, S 1986. Was ist der Mensch? Anthropologie des Judentums. Tübingen: Mohr.

Boegner, A 1878. s v Colère de Dieu. ESCR.

Brotzman, E R 1988. Man and the meaning of נפש.. BS 145(580), 400-409.

Caplice, S J 1974. An apotropaion against fungus. JNES 33(3), 345-349.

Cohen, H R 1971. s v Poison. EJ.

Darwin, C 1904. The expression of the emotions in man and animals. London: John Murray.

Dirvin, R 1994. Metaphor and nation: Metaphors Afrikaners live by. Frankfurt am Main: Peter Lang. (Duisburger Arbeiten zur Sprach- und Kulturwissenschaft 22.)

Douglas, M 1975. Implicit meanings: Essays in anthropology. London: Routledge \& Kegan Paul.

Eichrodt, W 1961. Theology of the Old Testament, vol 1. $6^{\text {th }}$ ed. London: SCM.

Ekman, P, Levenson, R W \& Friesen, W V 1983. Autonomic nervous system activity distinguishes among emotions. Science 221, 1208-1210.

Ellsworth, P C \& Scherer, K R 2002. Appraisal processes in emotion, in Davidson, R J, Goldsmith, H \& Scherer, K R (eds), Handbook of Affective Sciences, 1-64. Oxford: Oxford University Press.

Faessler, M 1997. Tel un souffle brûlant, in Pachet, $P$ (ed), La colère: Instument des puissants, arme des faibles, 91-108. Paris: Éditions Autrement. (Collection morales 23.)

Frazer, J G 1934. The fear of the dead in primitive religion. London: MacMillan.

Frijda, N H 1989. Les théories des émotions: Un bilan, in Rimé, B \& Scherer, K R (eds) 1989. Textes de base en psychologie: Les émotions, 21-66. Neuchâtel, Paris: Delachaux et Niestlé.

Gruber, M I 1980. Aspects of nonverbal communication in the Ancient Near East. Rome: Biblical Institute.

Hallie, P P 1967. s v Stoicism. EncPh.

Haney, H M 1960. The wrath of God in the former prophets. New York: Vintage.

Hanson, R P C 1946-7. The wrath of God. ET 58, 216-218.

Herion, G A 1992. s v wrath of God. AncB Dictionary.

Heschel, A J 1962. The prophets, part II. New York: Harper Colophon.

Johnson, A R 1964. The vitality of the individual in the thought of Ancient Israel.

Cardiff: University of Wales Press.

Kilpatrick, T B 1908. s v Anger. ERE.

Köhler, L 1953. Der hebräische Mensch. Tübingen: Mohr.

Köhler, L 1966. Theologie des Alten Testaments. 3.Aufl. Tübingen: Mohr.

Kotzé, Z 2004. The conceptualisation of anger in the Hebrew Bible. DPhil dissertation, University of Stellenbosch. 
Kövecses, Z 1990. Emotion concepts. New York: Springer.

Kövecses, Z 1995a. Metaphor and the folk understanding of anger, in Russell, J A et al (eds), Everyday conceptions of emotion: An introduction to the psychology, anthropology and linguistics of emotion, 49-71. Dordrecht: Kluwer Academic Publishers.

Kövecses, Z 1995b. Anger: Its language, conceptualisation, and physiology in the light of cross-cultural evidence, in Taylor \& MacLaury 1995:181-196.

Kövecses, Z 2002. Metaphor: A practical introduction. Oxford: Oxford University Press.

Kruger, P A 1998. "Nonverbal Communication" in the Hebrew Bible: A few comments. JNSL 24(1), 141-164.

Kruger, P A 2000a. A cognitive interpretation of the emotion of anger in the Hebrew Bible. JNSL 26(1), 181-193.

Kruger, P A 2000b. The obscure combination in Isaiah 30:27: Another description for anger? JNSL 26(2), 155-162.

Kruger, P A 2000c. The obscure combination כבד מש:אה in Isaiah 30:27: Another description of anger? JNSL 26(2), 155-162.

Kutsch, E 1965. "Trauerbräuche" und "Selbstminderungsriten" im Alten Testament. $\operatorname{ThSt}(B)$ 78, 25-42.

Lakoff, G \& Johnson, M 1980. Metaphors we live by. Chicago, IL: University of Chicago Press.

Lauha, R 1983. Psychophysischer Sprachgebrauch im Alten Testament. Helsinki: Suomalainen Tiedeakatemia.

Levenson, R W et al 1991. Emotion, physiology, and expression in old age. Psychology and ageing 6, 28-35.

Levenson, R W et al 1992. Emotion and autonomic nervous system activity in the Minangkabau of West Sumatra. Journal of Personality and Social Psychology 62, 972-988.

Matsuki, K 1995. Metaphors of anger in Japanese, in Taylor \& MacLaury 1995:137151.

Mikolajczuk, A 1998. The metonymic and metaphoric conceptualisation of anger in polish, in Athanasiadou \& Tabakowska 1998:153-191.

Morris, L 1952. The wrath of God. ET 63(5), 142-5.

North, R 1995. Did the ancient Israelites have a heart? BiRe, 11(3), 33.

Pedersen, J 1959. Israel, its life and culture, I-II. London: Oxford University Press.

Podella, T 1997. Reinheit. Altes Testament. TRE 28, 477-483.

Robinson, H W 1925. Hebrew psychology, in Peake, A S (ed), The people and the Book, 353-382. Oxford: Claredon.

Scherer, K R 2001. The nature and study of appraisal: A review of the issues, in Scherer, K R, Schorr, A \& Johnstone, T (eds), Appraisal processes in emotion: Theory, methods, research, 369-391. New York: Oxford University Press.

Schmidt, W 1964. Anthropologische Begriffe im Alten Testament. EvTh 24(7), 374390.

Schroer S \& Staubli T 1998. Die Körpersymbolik der Bibel. Darmstadt: Wissenschaftliche Buchgesellschaft.

Simpson, J W 1988. s v Wrath. ISBE. 
Smith, W R 1923. Lectures on the religion of the Semites. London: A \& C Black. Stöger, A 1970. s v Wrath. Bauer Encyclopedia of Biblical Theology.

Tasker, R V G 1980. s v Wrath. IBD.

Taylor, J R \& MacLaury, R (eds) 1995. Language and the cognitive construal of the world. Berlin: Mouton.

Taylor, J R \& Mbense, T G 1998. Red dogs and rotten mealies: How Zulus talk about anger, in Athanasiadou \& Tabakowska 1998:191-226.

Vögtle, A 1965. s v Zorn. LThK.

Von Harnack, A 1985. Marcion. Das Evangelium vom fremden Gott. Darmstadt: Wissenschaftliche Buchgesellschaft.

Von Meyenfeldt, F H 1950. Het Hart (לבב, לבב) in het Oude Testament. Leiden: Brill. Vorwahl, H 1932. Die Gebärdensprache im Alten Testament. Berlin: Emil Ebering. Weill, J 1926. Le sense de נפש dans Prov 23:7a. ZAW 44, 62-63.

Wenham, G J 1981. The theology of unclean food. EQ 53, 6-15.

Wenham, G J 1983. Why does sexual intercourse defile (Lv 15:18). ZAW 95, 432434.

Westermann, C 1981. Der Begriff des Zornes Gottes in der Prophetie, in Jeremias, J \& Perlitt, L (Hrsg), Die Botschaft und die Boten: Festschrift für Hans Walter Wolff zum 70. Geburtstag, 147-156. Neukirchen-Vluyn: Neukirchener Verlag.

Wolff, H W 1973. Anthropologie des Alten Testaments. München: Kaiser Verlag.

Wright, D P 1987. The disposal of impurity: Elimination rites in the Bible and in Hittite and Mesopotamian literature. Atlanta, GA: Scholars Press. (SBL.DS 101.)

Yu, N 1995. Metaphorical expressions of anger and happiness in English and Chinese. Metaphor and Symbolic Activity 10, 59-92. 